\title{
Prenatal Diagnosis of a De Novo Partial Trisomy 17q Case Associated with Increased Nuchal Translucency, Hypoplastic Left Heart Syndrome, Cerebral Anomalies: Case Report
}

\author{
Artmış Ense Kalınlığı, Hipoplastik Sol Kalp Sendromu, \\ Serebral Anomaliler ile İlişkili \\ De Novo Parsiyel Trizomi 17q'lu Olgunun Prenatal Tanısı
}

\author{
Mehmet TÜRE, ${ }^{a}$ \\ Şebnem ÖZEMRI SAĞ, ${ }^{a}$ \\ Emine Tuna GÜLTEN, ${ }^{a}$ \\ Betül ESER, ${ }^{b}$ \\ Serdar ŞAHINTÜRK, ${ }^{a}$ \\ Bilge ÇETINKAYA DEMIR, ${ }^{c}$ \\ Tahsin YAKUTa
}

${ }^{a}$ Department of Medical Genetics,

'Department of Obstetrics and

Gynaecology,

Uludağ University Faculty of Medicine,

Bursa

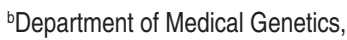

Balıkesir University Faculty of Medicine,

Balıkesir

Geliş Tarihi/Received: 29.05 .2014

Kabul Tarihi/Accepted: 13.10 .2014

Yazışma Adresi/Correspondence:

\section{Betül ESER}

Balıkesir University Faculty of Medicine, Department of Medical Genetics,

Balıkesir,

TÜRKIYE/TURKEY

drbetuleser@gmail.com

\begin{abstract}
Partial trisomy of distal 17q is rare. Until now, 32 cases of partial trisomy for the distal region of $17 q$ were reported. Our case has multiple anomalies, such as increased nuchal translucency, hypoplastic left heart syndrome and cerebral anomalies by routine prenatal ultrasonografic screen. Our case's karyotype was determined as $46, \mathrm{XX}$,der(4)(17qter $\rightarrow 17 \mathrm{q} 21:: 4 \mathrm{pter} \rightarrow 4 \mathrm{qter}) \mathrm{dn}$ due to de novo chromosomal rearrangement. Cytogenetic results performed with FISH analysis. Our case is the first reported case of a de novo derivative chromosome 4 arising from partial trisomy 17q. The $4 \mathrm{p}$ terminal deletion was not determined by FISH with the $4 \mathrm{p}$ telomere probe so we considered that the clinical findings of our case associated with partial trisomy $17 \mathrm{q}$. We have reported this case to contribute to the literature and to provide benefit in the genetic counceling.
\end{abstract}

Key Words: Chromosome 17 trisomy; prenatal diagnosis

ÖZET Distal 17q'nun parsiyel trizomisi nadirdir. Bugüne kadar distal 17q parsiyel trizomili 32 olgu rapor edilmiştir. Bizim olgumuz rutin prenatal ultrasonografi ile tespit edilmiş artmış ense kalınlığı, hipoplastik sol kalp sendromu ve serebral anomaliler gibi pek çok anomalilere sahiptir. Olgumuzun karyotipi de novo kromozomal yeniden düzenlenmeye bağlı 46,XX,der(4)(17qter $\rightarrow 17 q 21:: 4$ pter $\rightarrow$ 4qter)dn olarak belirlendi. Sitogenetik sonuçları FISH analizi ile doğrulandı. Bizim olgumuz, parsiyel trizomi 17q'dan kaynaklanan de novo derivatif kromozom 4'e ait bildirilen ilk vakadır. $4 \mathrm{p}$ telomer probu ile yapılan FISH analizinde $4 \mathrm{p}$ terminal delesyonu saptanmadığından olgumuzun klinik bulgularının parsiyel trizomi 17q ile ilişkili olduğunu düşünüyoruz. Bu vakayı, literatüre katkı sağlamak ve genetik danışma süresine yardımcı olmak amacıyla bildirdik.

Anahtar Kelimeler: Kromozom 17 trizomi; prenatal tanı

Turkiye Klinikleri J Gynecol Obst 2016;26(2):125-8

$\mathrm{F}$ ull trisomy 17 has never been reported in liveborns. It has been recorded in spontaneous abortions and but with an extremely low incidence. ${ }^{1}$ Partial trisomy $17 q$ is rare. Until now, 32 cases of partial trisomy for the distal region of $17 \mathrm{q}$ were reported either inherited or de novo..$^{2-8}$ A derivative chromosome 4 due to partial trisomy of chromosome $17 q$ has never been described, to our knowledge. We demonstrated that the fetus was a carrier of a de novo derivative chromosome 4 arising from partial trisomy 17q. Use of fluorescent in situ hybridization (FISH) analysis permitted the identification of the chromosome 17q breakpoint regions and confirmed the cytogenetic results. 


\section{CASE REPORT}

We present the case of a 32 year old woman who was referred at 13 weeks' gestation to our genetic diagnostic center because of routine prenatal ultrasonografic screen results indicating an increased nuchal translucency. As the mother's medical and obstetrical history was unremarkable. Both parents were apparently normal. The couple was not consanguineous. There was no family history of miscarriages, malformations or developmental delay. Their first pregnancy resulted in a healthy girl child. The present pregnancy was second. Increased nuchal translucency was determined in fetus at 13 weeks' gestation by routine prenatal ultrasonografic screen. Both parents received nondirective genetic counseling and signed consent form. Chorionic villus sampling (CVS) was performed at 13 weeks' gestation, to determine the fetal karyotype. Cytogenetic analysis showed a 46,XX,add(4)(p16)[9]/46,XX[11] mosaic karyotype. The parents' karyotypes were normal. The chromosomal abnormality in the fetus occurred de novo. At 18 weeks' gestation, the detailed ultrasonografic screening revealed cerebral and cardiac multiple anomalies. Cerebral abnormalities included tight cisterna magna, presence of colpocephaly at lateral ventricles, suggesting hypoplasia of the corpus callosum. Fetal echocardiography revealed hypoplastic left heart syndrome, includes under development of the left ventricle, aorta, and aortic arch, as well as mitral hypoplasia. No dysmorphic abnormalities was observed in the case who was a fetus on the prenatal ultrasound examination. Amniocentesis was performed at $18+3$ weeks' gestation, to confirme the result of CVS and to exclude the placental mosaicism and pseudomosaicism. Methaphase chromosome preparations were obtained from the amniotic fluid cells according to standard long term tissue culture procedures. Chromosomes were analyzed with Giemsa banding at the resolution level of 400-500 bands. The karyotype was determined as 46,XX,der(4) (17qter $\rightarrow 17 q 21:: 4$ pter $\rightarrow 4$ qter)dn (Figure 1). To confirm the cytogenetic results, FISH analysis was performed with the ToTelVys-

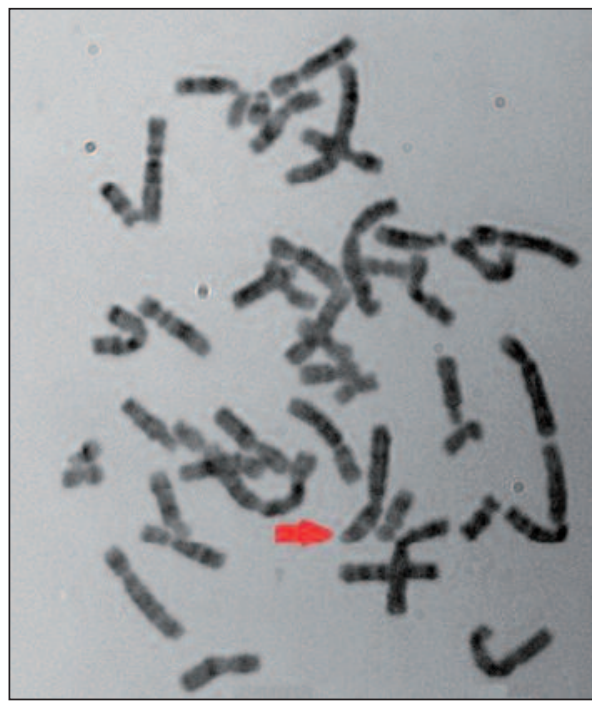

FIGURE 1: The karyotype was determined as 46,XX,der(4)(17qter $\rightarrow 17 q 21::$ 4 pter $\rightarrow 4$ qter)dn.

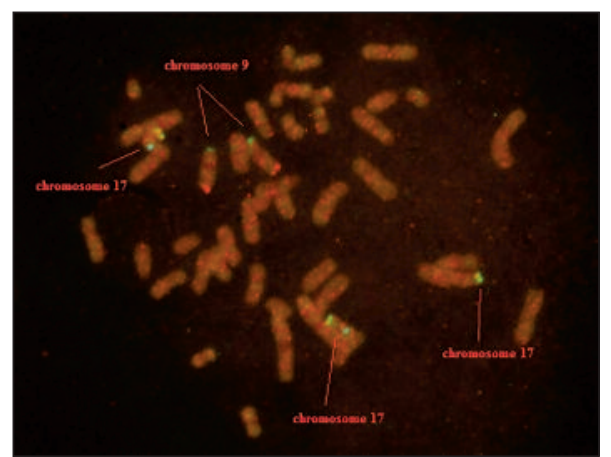

FIGURE 2: FISH analysis revealed a partial trisomy $17 q$ by ToTelVysion Mix\#9 FISH prob.

ion Mix\#9 FISH prob (TelVysion 17q spectrum Green and Spectrum Orange, cep17 Spectrum Aqua, TelVysion 9p Spectrum Green, TelVysion, 9q Spectrum Orange ) and TelVysion 4p spectrum Green FISH prob, FISH analysis revealed a partial trisomy 17q (Figure 2). 4p terminal deletion could not be detected by FISH experiment (Figure 3).

Both parents received nondirective genetic counseling. The parents decided to terminate the pregnancy. The fetus terminated at 20 weeks of gestation. We didn't compare prenatal ultrasonografic screen results with fetal autopsy examination to detect structural births defects following the termination of pregnancy. Because the parents didn't allow the fetal autopsy examination. 


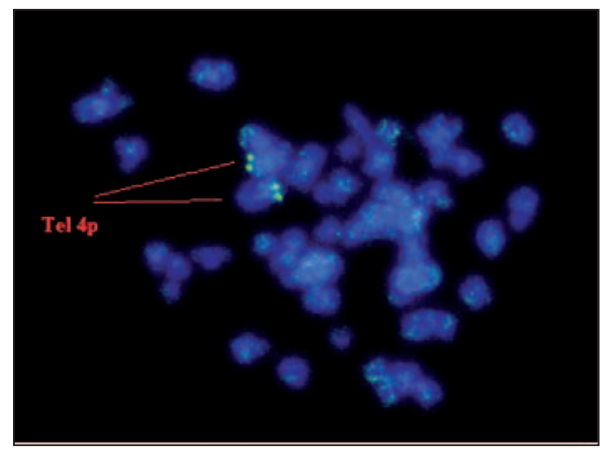

FIGURE 3: $4 p$ terminal deletion could not be detected by TelVysion $4 p$ spectrum Green FISH prob.

\section{DISCUSSION}

Aneuploidy is found in at least $5 \%$ of all clinically recognized pregnancies. ${ }^{9}$ Complete trisomy 17 has never been reported in liveborns and rarely in spontaneous abortions. ${ }^{1}$ Thirty-two cases of partial trisomy for the distal region of $17 \mathrm{q}$ were reported in the literature till now. ${ }^{2-8} 29$ cases of them were liveborn and three cases were diagnosed during the prenatal diagnosis. Our patient carried a de novo partial trisomy 17q. Partial trisomy 17q releated to recognizable dysmorphic evidences and psychomotor retardation. ${ }^{6}$ Mental and growth retardation, microcephaly, high forehead, frontal bossing, temporal retraction, short and broad nose, broad and flat nasal bridge, large mouth with down-turned corners, thin upper lip, cleft palate, low-set and malformed ears, short and webbed neck, limb shortness and skeletal anomalies, abnormalities of genital, brain, heart and kidney were reported in partial trisomy17q patients. ${ }^{6,7}$

Cordier et al. first reported a combination of partial trisomy $17 q$ and monosomy $5 p$ in fetus. ${ }^{8}$ In this case, nearly every phenotypic sign observed prenatally on the ultrasound scan. The fetus showed most of the ultrasound and clinical findings of partial trisomy 17q. Microcephaly, wide anterior fontanelle, hypertelorism, micrognathia, short and broad nose, polydactyly, cerebellar hypoplasia, multiple heart anomalies and genital abnormalities found in this fetus. The pathologic examination confirmed the prenatal findings. We examined our case only by prenatal ultrasound and fetal echocardiography. Cerebral and heart anomalies from reported findings of partial trisomy $17 q$ determined in our fetus. The parents didn't allow the fetal autopsy examination. Therefore the dysmorphic characteristics of the chromosomal abnormalities of our case were not detect.

One case of trisomy of distal $17 \mathrm{q}$ and a deletion of distal 9p was reported to have been identified prenatally. ${ }^{10}$ This fetus had a monosomy 9p24.3-pter (the critical region of the 9p deletion syndrome is in 9p22-p23) so Brisset et al considered that the dysmorphism findings (high forehead, large mouth with down-turned corners, short and broad nose, low-set and malformed ears and increased nuchal translucency) of the case, observed on fetal examination, were associated with the distal trisomy 17q. The case had cerebral and heart anomalies, as well as dysmorphic features. Our case illustrated abnormalities of brain and heart of partial trisomy 17q described in the literature.

Conventional cytogenetic techniques used to identify the origin of an extra segment of a chromosome in the unbalanced chromosomal translocation. In some case, these techniques alone is not sufficient to determine this origin and FISH experiment is frequently used. In this study, we used a combination conventional chromosomal technique and FISH. In present case, the $4 p$ terminal deletion was not determined by FISH with the $4 \mathrm{p}$ telomere probe so we considered that the clinical features could not be related to the classical $4 p$ terminal deletion syndrome. We suggest that the clinical findings of our case associated with partial trisomy $17 q$.

In conclusion our case is the first reported case of a de novo derivative chromosome 4 arising from partial trisomy 17q. We could not show the ultrasound features of these chromosomal abnormalities and their correlation with autopsy findings. Even so, we have reported this case to contribute to the literature and to provide benefit in the genetic counceling. 
1. Hassold T. Mosaic trisomies in human spontaneous abortions. Hum Genet 1982;61(1):31-5.

2. Gallien JU, Neu RL, Wynn RJ, Steinberg-Warren N, Bannerman RM. Brief clinical report: an infant with duplication of 17q21 lead to 17qter. Am J Med Genet 1981;8(1):111-5.

3. Ondo S, Madokoro H, Sonoda T, Ohba K. Sibs lacking characteristic features of duplication of distal 17q. J Med Genet 1989;26(7):465-8.

4. Cotter PD, Stewart NL. Partial trisomy $17 q$ and monosomy $9 p$ due to a familial translocation. Ann Genet 1990;33(4):231-3.

5. Szego K, Rauer M, Baratta E, Hoo JJ. De novo concurrent $5 p$ deletion and distal $17 q$ du-

\section{REFERENCES}

plication identified by fluorescence in situ hybridization (FISH). Ann Genet 1993;36(4):224-7.

6. Sarri C, Gyftodimou J, Avramopoulos D, Grigoriadou M, Pedersen W, Pandelia E, et al. Partial trisomy 17q22-qter and partial monosomy Xq27-qter in a girl with a de novo unbalanced translocation due to a postzygotic error: case report and review of the literature on partial trisomy 17qter. Am J Med Genet 1997;70(1):87-94.

7. Kelly BD, Becker K, Kermode V, Stallings RL, Murphy RP, Green AJ, et al. Dysmorphic features and learning disability in an adult male with pure partial trisomy 17q24-q25 due to a terminal duplication. Am J Med Genet 2002;112(2):217-20.
8. Cordier AG, Braidy C, Levaillant JM, Brisset $S$, Maurin ML, Mas AE, et al. Correlation between ultrasound and pathological examination in a prenatal diagnosis of Cri du Chat syndrome associated with partial trisomy $17 \mathrm{q}$. Prenat Diagn 2008;28(5):463-5.

9. Hassold T, Hunt P. To err (meiotically) is human: the genesis of human aneuploidy. Nat Rev Genet 2001;2(4):280-91.

10. Brisset S, Kasakyan S, L'Herminé AC, Mairovitz V, Gautier E, Aubry MC, et al. De novo monosomy 9p24.3-pter and trisomy 17q24.3-qter characterised by microarray comparative genomic hybridisation in a fetus with an increased nuchal translucency. Prenat Diagn 2006;26(3):206-13. 